\title{
S5ynthesis
}

International Scientific Conference of IT and Business-Related Research

\section{GLOBALIZACIJA I KORUPCIJA}

\section{GLOBALIZATION AND CORRUPTION}

\author{
Branko Balj ${ }^{1}$, Danijela Batinić \\ ${ }^{1}$ Univerzitet u Novom Sadu, Ekonomski fakultet, Subotica, Srbija
}

\begin{abstract}
Apstrakt:
Globalizacija u vidu neoliberalne globalizacije postala je načinom zloupotrebe iskustvene nauke, rodno mesto ekonomskog i teorijskog fundamentalizma koji podastire svako moralno, političko i pravno delanje. Taj duh vremena, koji je na snazi od sedamdesetih godina $\mathrm{XX}$ veka pa sve do danas, postao je pretnja opstanku bilo kog oblika drugosti i prouzrokovao je pretnju u rasponu od globalne ekonomske krize do neslućenog socijalnog raskola u svetskim razmerama. Jedno od sredstava tog vremena, čija mera je profit i isključivo profit, ispostavio je i plodonosno polje neoliberalne globalizacije. Pozivati se na palu ljudsku prirodu predstavlja promašaj od samog početka.
\end{abstract}

\section{Ključne reči:}

globalizacija, neoliberalna globalizacija, tržišni fundamentalizam, korupcija, industrija korupcije.

Samo vreme današnje svedoči da zdravorazumska, obična, svakodnevna svest glorifikuje dva pojma: globalizaciju i globalni svet. Toj glorifikaciji pridružuje se naučna svest, naročito kada je matematizirana, bilo da se radi o sociološkoj, politikološkoj ili pak ekonomskoj, i to u smislu da je vreme pragmatičnog ljudskog mišljenja - delanja neizostavno obavezujuće, te da u tom svetskom trendu stanuje spasonosno kako za svet, tako i za sve unutarsvetsko događanje. Toj i takvoj glorifikaciji, u smislu izvođenja radova, priključuju se i održavaju je u životu vlade onih zemalja koje se nalaze u tranziciji ili posttranzicionom vremenu kao i vlade ekonomski najrazvijenijih zemalja. Međutim, iza ove lažno pozitivne pohvale globalizacije stoje moćne multinaiconalne korporacije sa svojim precizno utvrđenim profitnim interesima, koji su predstavljeni kao svetinja ovog sveta.

Međutim, globalizacija predstavlja procesualnost, pre svega, novovekovne nauke koja je radikalno otvorila pitanje odnosa filozofije s jedne strane i nauke s druge strane, a time i prenapregnutost odnosa nauke i religije, umetnosti, književnosti i jezika. Takvo radikalno otvaranje pitanja u XX veku, a pogotovu u drugoj polovini XX veka usmerilo je znanje (nauku) ka stazi neoliberalne globalizacije koja u profitonosnim temeljima ekonomije zahteva potpunu poslušnost etike, politike i prava.

\section{Abstract:}

Neo-liberal globalization, as a form of globalization, resulted from the misuse of experiential science and has become the birthplace of economic and theoretical fundamentalism that subordinates every moral, political and legal action. The spirit of the time, which has been in force since the 1970s, has become a threat to the survival of any form of otherness and imposed enormous threats ranging from the global economic crisis to the unimagined social schism on a global scale. One of the means of that time, which measures everything through profit, has triggered the fruitful industry of corruption, whose discourse can be deconstructed only by the re-evaluation of the spirit of neo-liberal globalization. To refer to the concept of a fallen human nature is a failure from the very start.

\section{Key words:}

globalization, neoliberal globalization, market fundamentalism, corruption, corruption industry.

Ta kvazipozitivna pohvala globalizacije predstavlja pohvalu prakse globalizacije koja podastire, u svom procesu perpetuiranja, samo onaj i onakav teorijski razgovor koji doprinosi legitimnosti takve prakse. S druge strane, ostaje onaj oblik teorijskog razgovora koji kritički propituje taj i takav konceptualno-praktični obrazac sveta i života, i koji uviđa kuda vodi takva praksa globalizacije.

Dakako, ljudsko, individualno i grupno delovanje proizvedeno je od samog mišljenja - uma. Zato se i um postavlja kao problem u rasponu od nade do njegovog "pomračenja" (Horkheimer, 1988).

Imajući to u vidu, potrebno je postaviti nekoliko kritičkih pitanja u nameri da ispitamo:

a) odnos pragmatičnog razuma - delovanja i praktičnog uma - delovanja na njegovom tragu;

b) odnos unutarsvetskog i svetskog kao problema kritičke refleksije;

c) odnos globalizacije kao rezultata novovekovnog filozofskog razgovora i moguća kritika istog;

d) moderno i postmoderno viđenje globalizacije iz perspektive uma, njenu tajnu i razrešenje. 
Termin pragmatično u svojoj istorijskoj dimenziji, kako na to s pravom ukazuje Adorno (1986), nije uvek sadržavao ono što se pod njim danas podrazumeva, a to je da reći pragmatično- znači korisno.

U tom smislu, pragmatično delovanje za svrhu ima ostvarenje koristi, pa se i sama korist javlja kao mera istine i istinskog života i u gnoseološkom i u vrednosnom smislu. Jednostavno rečeno: da bi se ostvario neki korisni cilj, potrebno je izabrati ona sredstva koja služe kao instrumenti kojima se obezbeđuje ostvarenje cilja. Pragmatično mišljenje - delovanje nalazi se u samoproduktivnom razgovoru sa scijentizmom, koji svoju filozofiju nizom posredovanja mogu da misle sa Dekartovim htenjem i mišljenjem matematizirane fizike. Upravo na taj način pragmatizam pristupa nauci kao sredstvu za realizaciju svojih ciljeva. To novovekovno pragmatično mišljenje - delovanje zaslužuje da bude predmetom kritike praktičnog uma, onog praktičnog uma koji nije izrazito subjektivno određen u smislu instrumentalno-subjektivnog uma, iz više razloga. Naime, u Platonovoj podeli nauka na teorijsku i praktičnu stanuje Aristotelovo kritičko polazište za podelu nauka na: teorijsku (metafizika, fizika i matematika), praktičnu (etika, politika, ekonomija i pravo) i poetičku (tehne, retorika i poetika). Ta podela nauka bila je važeća i u novovekovnoj filozofiji, a u smislu praktičnog uma ona je predstavljala kritičku refleksiju veza i prelaza kao i principa objedinjavanja između etike, politike, ekonomije i prava. Kod Aristotela je vidljivo ne samo strogo pojmovno diferenciranje unutar praktičnoguma, tj. praktične filozofije, nego i napor mišljenja da se dođe do jedne stvarne celovitosti (celine) u kojoj je etičko-političko mišljenje/delovanje starije u odnosu na ekonomsko-pravno. Ta otvorena celovitost etičko-političkog mišljenja/delovanja nije totalizujuća za ekonomsko-pravno ljudsko delovanje, nego je više instrumentalno-regulativna. Upravo istina instrumentalno-regulativnog kao temeljnog ljudskog delovanja izvedena je uz pomoć kritičke refleksije realnog života u polisu i oikosu sa svrhom da se život u zajednici učini pravednijim, dobrim, korisnijim i zakonitijim nego što on zaista i jeste. Budući da sve ono što je ljudsko može da bude i bolje i gore, Aristotel ukazuje na to da je čovekova žudnja za bogatstvom, moći i ugledom (slavom) često pogubna za mnoge polise i građane tog polisa.

Od Aristotelovog vremena do današnjeg dana čovek, vođen isključivo instrumentalno-antropološkim načinom mišljenja/ delanja, „napredovao” je u smislu osvajanja prirode posredstvom prelaza iz tehne u tehniku i ove u tehnologiju, čija je mera izračunljivost, preglednost, egzaktnost, planljivost i kalkulativnost. Čovek, vodeći praktičan život, svoj smisao iscrpljuje, kako bi Heidegger rekao, u pristupu (odnosu) drvetu samo kao sirovini drvnoprerađivačke industrije, što ga vodi osvajanju i porobljavanju, odnosno širenju prostora bezzavičajnosti. Međutim, nužno je i istaći da taj instrumentalno - kalkulativno - pragmatički um ne predstavlja, svakako, zadnju reč uma, ali zaslužuje ne glorifikaciju nego kritiku od strane praktičnog uma i njegove potrebe za građenjem otvorenog jedinstva veza i prelaza između etike- politike - ekonomije i prava. Razlog upravo leži u tome što se između praktičnog i pragmatičnog bivstvovanja ne može zauvek staviti znak jednakosti. Nada stanuje u čoveku kao umnom biću čiji horizont događanja u suštinskom smislu stanuje u mogućnosti - delatnosti nadilaženja pragmatično ekonomskog kao koristonosnog događanja.

Pri upotrebi termina globalizacija i globalni svet često se previđa, od strane upotrebljivača, distinkcija između procesualnosti i penetrativnosti tog termina i termina kojim se označava stanje sveta, pri svemu tome ni na kraj pameti im ne pada potreba da postave problem u smislu odnosa i pitanja između unutarsvetskog bivstvujućeg i sveta, kao i postavljanje pitanja o singularnom i pluralnom mišljenju sveta, nego globalizaciju hoće da predoče kao nauku o svetu, ne znajući da nauka o svetu nije moguća u smislu posebne nauke, nego da je moguće pitanje sveta tek postaviti kao filozofsko pitanje i problem.

A još je Platon upotrebljavao termin globalnog prilikom razmatranja četiri moguća odnosa između jednog i mnoštva. Tako on u Sofistu govori o penetrativnom, globalnom, konstelativnom i separativnom odnosu jednog i mnoštva. Upravo time se ukazuje na dijalektički prelaz i blizinu jednog i mnoštva.

Globalisti i mondijalisti stoje na stanovištu da je globalizacija nužan i prirodan proces unutarsvetskog bivanja po globalno utvrđenom dinamičkom procesu, kao i stazama i putevima, i to tako da se širi i ispunjava svetsko. Taj proces je teleološki i treba da rezultira stanjem u kome će sve posebnosti biti potrte i svaki pluralitet biće suvišan, a čovek će dospeti do svetskog građanstva ostavljajući iza sebe običaj, kulturu, narod, naciju, vlastiti karakter i jezik.

U vezi sa ovakvim mišljenjem/delovanjem nameće se nekoliko karakterističnih pitanja:

1. Šta za njih znači nužnost i prirodnost? Zar u ljudskim delovanjima isključivo važi delovanje prirodnih zakona, pa samim tim i zakon jačeg? Zar to ne vodi ratu svih protiv svih (na šta je još ukazivao Platon u Zakonima, pre Hobsa). Nije li opet aktuelan Hobsov Levijatan i njegovo shvatanje praktičnog uma?

2. Zar unutarsvetsko može da ispuni svetsko? Kakvo je to shvatanje gde regionalno ljudsko delovanje hoće da bude koncept i obrazac za sva druga regionalna delovanja i gde regionalno hoće da se nametne kao svetsko/globalno? Kakvo je to mišljenje prostora sveta? Zar se svet misli kao prazan prostor, zar on sam nije „prostirući prostor” ili, kako bi to Eugen Fink rekao: „On (svet, prim. B.B.) je iznad svega, i izvan najdaljeg Tamo i u onom najbližem Ovde. On se takoreći njiše između Ovde, štaviše, onoga Ovde mog tela i zamislivog najspoljašnjijeg Tamo otvorene beskrajnosti, ali tako da Ovde i Tamo nastaju polazeći od njegovog horizonta... Prostor sveta ne treba poimati po modelu res extensa, jer je on čisti extensio, prostirući prostor... ono nije kretanje koje bi mi ikada mogli da iskusimo: nego je ono prapretpostavka koja omogućuje sve naše iskustvo" (Eugen, 1989, str. 169). Ako unutarsvetsko bivanje teži svetskom bivanju u smislu dijalektike prelaza, a ne dominacije i totalitarizma, onda je to moguće upravo time što je omogućeno od svetskog bivanja, koje je kao takvo apriorno pluralno i time omogućuje pluralitet unutarsvetskog kao praktičnog, tj. kao prelaza između moralnog, političkog, ekonomskog i pravnog ljudskog delovanja. Tek na taj način pri unutarsvetskom stanuje u njegovoj blizini svetsko. U protivnom, svako unutarsvetsko bivanje, ukoliko hoće da se nametne kao svetsko, jeste jednodimenzionalno, odnosno totalitarno, s druge strane, svako svetsko bez unutarsvetskog kao pluralnog predstavlja nametanje metapriča sa raznim iskazima kojima pripada i globalizam. Otuda je san o jednoj državi, jednom društvu, jednoj kulturi, jednom jeziku, jednoj tehnologiji san pogubnog ideološkog diskursa vladanja unutar koga se varirao XX vek, označen kao vek razvoja. Zaks (2001, str. 83)će reći: „Rezultat je ogroman gubitak raznolikosti”. Međutim, pravo pitanje glasi: kada je otpočeo gubitak raznolikosti?

Gubitak raznolikosti za rezultat ima gubitak Drugog ne samo po pitanju jezika kao najtoplije prostorije čovekove kuće (Gadamer, 1978, 2000a, 2000b), nego uopšte kulturnog identiteta (tradicije, vere, jezika, naroda), pa ako „pri opasnosti stanuje 
spasonosno" (Helderlin) onda nada stanuje u potpunom priznanju raznolikosti, a to jeste bitan zahtev i izazov vladajućem duhu vremena.

Globalizacija i globalizam kao proces i kao stanje, po mišljenju poststrukturalista, postistoričara i postmodernista, a kao najreprezentativnije ističemo: Fukoa, Bodrijara, Deridu i Liotara, - svoj vrhunac dosegnuće sa duhom moderne, koji ne zaslužuje ništa drugo nego nego dekonstrukciju, destrukciju, napuštanje i definitivan raskol, iz prostog razloga jer ništa novo i obećavajuće ne postoji na tragu mišljenja o metapričama koje su rezultat uma. Svi ovi diskursi, a čija se relevantnost ne ogleda u dijagnozi stanja unutarsvetskog događanja, manje-više počivaju na reinterpretaciji Ničea, i bliže, Hajdegerovog misaonog napora za prevladavanje klasične istorije metafizičkog načina mišljenja, koje je zapostavilo od Platona i Aristotela pa nadalje, pitanje problem smisla bivstva bića, koje treba eksplicirati u vremenu, a ne isporučivati ga antropološko-instrumentalnom odnosu.

Međutim, problem globalizacije ne pripada samo vrhovima moderne. Prethodni procesi globalizacije, kao saepohalni procesi, a u saglasnosti sa razvojem tehnea (zanata i veština) nosili su ista ambivalentna činjenja koja su skončavala u osvajanju, pljačkanju, porobljavanju drugih naroda i njihovih običajnokulturnih formi življenja. Platon i Aristotel, a da ne kažemo antički istoričari, na svojevrstan način svedoče o tome, a kasnije posebno Hegel, iako je upravo Hegel postao predmetom žestoke kritike mnogih postmodernih mislilaca. Po njima, Hegelovo mišljenje kretanja duha subjektivnog, objektivnog i apsolutnog, uz imanentno posredovanje, predstavlja put ka apsolutu, ka celini, a njegov filozofski sistem, koji vrhuni sa totalitetom, u suštini je totalitaran. Zato Kjerkegor, Šopenhauer, Niče, Hajdeger, a potom i Adorno, a za njima poststrukturalisti, postistoričari i postmodernisti stoje na stanovištu da je put od Hegelovog određenja filozofije „kao mislima obuhvaćenog vremena” put ka prelazu filozofije u ideologiju, a da je svaka ideologija totalitarna, te da se kao takva pretvara u negativnu utopiju. Isto tako Hegelovo određenje istine kao celine, odnosno totaliteta, jeste trasiranje puta za prelaz totaliteta ka totalitarizmu. Hegel je otuda viđen i predočen kao totalitarni mislilac. Ali kritičari Hegelovi, gotovo da su zaboravili na dva suštinska problema o kojima nas Hegel izveštava i opominje, a to su:

1. Hegel ističe: „Broj je bespojmovan odnos.” Hegel upravo time raskriva da filozofija nije isto što i zdravorazumska svest, niti je isto što i matematika. U odnosu na tu svest, filozofija je „izokrenuta svest”. Takvom zdravorazumskom i matematskom načinu mišljenja, koji hoće sve da izmeri, izbroji, isplanira, pripadno je vreme uzajamnog potiranja interesa, odnosno interesni rat svih protiv svih. Hegel, iako hvali Dekartovo „Mislim, dakle, postojim”, okreće se protiv njegovog metoda mišljenja i svoj metodski put izlaže kroz kretanje duha, a ne broja, kalkula.

2. Upravo tim kretanjem duha, a posebno mišljenjem objektivnog duha, tj. praktičnog uma - duha Hegel veoma jasno izlaže novovekovni problem kolonizacije, tj. univerzalizacije logosa kapitala, ili horizonta građanskog sveta, koji je u svom hodu ispostavio više formi ili likova tog sveta. Likovi tog sveta variraju se od industrijalizma, potom postinudstrijalizma, kako mnogi sociolozi nazivaju stanje građanskog sveta, potom tehničke slike sveta, pa sve do lika globalizma kao samog vrha građanskog sveta. Upravo iz tog razloga što Hegelova analiza momenata praktičnog uma - duha u prelazima: apstraktnog prava, moraliteta, građanskog društva i građanske države - isporučuje pojmovni ključ za razumevanjem globalizacije koja je danas na delu; bez Hegela se moderan svet ne može ni pojmiti. Posebnu pažnju zaslužuje analiza funkcionisanja rastrgnutog bitka građanskog društva data u Fenomenologiji duha (odeljak: Zakon srdaca), a posebno u Filozofiji prava i Enciklopediji filozofijskih nauka. Po Hegelu, tajna razrešenja problema prisutnih u pojedinačnim građanskim društvima leži u hodu tih društava ka društvima pre građanskog racionaliteta, sa svrhom da se tamo izvezu sredstva i oruđa rada (tehnika i tehnologija) i da se za svoje proizvode pronađu „nova potrošačka usta”. U tom i takvom imperijalnom hodu i njegovim ambivalentnostima odvija se proces univerzalizacije građanskog društva koji građanska država posreduje, te da se ne bi od sebe uništilo vlastitim protivrečjima. Imajući to na umu, Hegel je mišljenja da praktičan um nije dovoljan sam sebi i on čini prelaz ka apsolutnom duhu i njegovim momentima: umetnosti, religiji i filozofiji.

Ovim pozivanjem i podsećanjem na Hegela hteli smo samo da ukažemo na to da je globalizacija samo jedan lik građanskog sveta, kojom se, uz mnogo šta valjanog, širila i pustinja osvajanja. Građanski svet se, istina, u mnogim aspektima usavršio u drugoj polovini XX veka.

Prema tome, globalizacija je pojmovno, pa ako hoćete i duhovno, pojmljena još sa Hegelovom novovekovnom filozofijom, a moderna ju je još savremenije pojmovno izdiferencirala i kao takvu predočila je kao predmet kritike postmoderne, mada je njena kritika zasnovana već samim pojmovnim razjašnjenjem.

Mišljenje moderne pripremljeno je i oblikovano od strane predstavnika prve i druge generacije kritičke teorije društva, a ne treba smetnuti s uma ni Lukača, a ni Bloha, pa ni Huserla, kao ni filozofe egzistencijaliste. Pored različitosti problema i metodoloških pristupa, moglo bi se reći da se zajednički predmet kritike ogleda u kritici savremenog industrijskog društva, kao jednodimenzionalnog društva koje zahteva jednodimenzionalnog čoveka. Na taj način čovek je upućen na put instrumentalne upotrebe uma sa svrhom apsolutnog ovladavanja prirodom i svođenjem svega ljudskog na resurs; ujedno, time je pripremljen i plodan teren za kritički razgovor o problemu globalizacije. Inače, kako drugačije razumeti Adornovu i Horkhajmerovu Dijalektiku prosvetiteljstva, Adornovu Negativnu dijalektiku, Markuzeovog Čoveka jedne dimenzije, Fromovo Imati ili biti, Horkhajmerovu Kritiku instrumentalnog uma, Habermasovu Nauku i tehniku kao ideologiju, Filozofski diskurs moderne. Ovi kritički razgovori svedoče o tome da takva proizvodnja unutarsvetskog zbivanja, predočena kao globalno događanje, mora postati predmetom kritičkog umskog uvida pomoću koga čovek i treba i mora da nađe izlaz iz „pustinje kojom bludi” (Heidegger), pod pretpostavkom da prevrednuje podastiranje nauke i tehnike instrumentalnom umu i okrene se ka „komunikativnom delovanju” i umu (J. Habermas). Time se izričito kaže da nije problem prisutan na strani nauke i tehnike, jer ništa demonsko u njima ne stanuje nego problem stanuje u pragmatično-instrumentalnoj upotrebi istih kao formi racionalnog ovladavanja prirodom i čovekom samim, narodima, državama i kulturama koje (forme vladanja) prete „užasom objektivnog" (E. Bloch).

Poststrukturalisti, postiistoričari i postmodernisti smatraju da je sve već dogođeno i da prisustvujemo „kraju istorije” ili simulaciji simulacije, tj. simboličkoj razmeni i smrti (Baudrillard) koju proizvodi i pronosi osvajačka težnja belog čoveka, tj. Bela mitologija (Derrida) sa svrhom dolaska do Prozirnosti zla. Zato će Fransoa Liotar da, u svom Raskolu kaže: „Smrt celini, aktivirajmo raskole". Nije li upravo ovovremena neoliberalna celina omogućila da je i politika i pravo kao i etika svedena i merena govorom novca, odnosno hrematističke ekonomije čija je svrha profit, odnosno neodmereno zgrtanje bogatstva koje otpočinje 
„zarobljavanjem države” te se time, navodno, sve pokriva „legalitetom"?! Međutim, da li svi ti sudovi stoje kao relevantni/ istiniti i da li je sve to baš tako? Da li se može tako radikalno kritikovati upravo ono što u bitnom smislu pripada čoveku: a to je um kao rodno mesto njegovo, kao njegovo bivstvo bića? Pa šta je čovek ako nije umno biće? Zar on svojim umom nije proizveo jedan realan svet koji je postao virtuelan, ali koji svedoči da njegovo unutarsvetsko i suviše odiše postvarenjem, kao sublimnim izrazom otuđenja, ali je, s druge strane, čovek svojim umnim uvidom, a u potrazi za smislom vlastitog bivstvovanja, raskrio u samim vrhovima modernog i postmodernog mišljenja svu besmislenost jednodimenzionalne globalizacije, bilo da se radi o pax americana ili pak o htenju da Evropa postane, takoreći, jedna država. Na delu su obe opcije, naročito posle urušavanja partijsko-birokratskog socijalizma, koji je neminovno zaprečio mogućnost demokratskog socijalizma, kao produktivnu antitezu globalizmu, koji pronose i proizvode multinacionalne korproacije, čija je svrha ubiranje profita (Berč \& Mihnjenko, 2012). Pri tome je sporedno da li taj profit potiče iz proizvodnje hrane ili trgovine oružjem, bitno je samo jedno: da on potiče $u$ što većim količinama.

Globalizam multinacionalnih korporacija, kao dosegnuti lik horizonta građanskog sveta, proizveo je globalne probleme, koje ili ne priznaje, ili pokušava osvojiti kao „programske tačke" (Oskar Negt) ili polazne stanice za ubiranje novih profita. Upravo pristupajući iz tog instrumentalnog ugla i upotrebljavajući instrumentalni um krajnje pragmatično, globalizacija nema odgovore na sledećih nekoliko pitanja/problema koje je sama proizvela:

- Globalni ekološki problem;

- Globalni problem siromaštva, i „pri preobilju bogatstva” (Hegel) ostaje trajno nerešiv;

- Globalni problem manjina, zatim „malih” naroda i „malih” kultura i jezika o čemu svedoči elementaran nedostatak sluha za potrebu i problem ideje pluraliteta, jer svet je pluralan,i to ne u smislu regionalnog mišljenja sveta, nego, doista, on jeste pluralan i samo kao takav može da se događa;

- Globalna proizvodnja savremenog tehnološkog i biotehnološkog oružja, kao i nehtenja ili nemogućnost kontrole istog;

- Globalni terorizam i permanentni ratovi, vođeni posle Drugog svetskog rata, pod doktrinom „ograničenih ratova ", a što je posledica neadekvatnog mišljenja ljudskih sloboda i prava. Iako su problemi kritički reflektovani, globalizacija koju pronose multinacionalne korporacije, a koje u prvi plan isturaju vlade ekonomski najrazvijenijih zemalja Zapada, kao i vlade onih zemalja koje se nalaze u tranzicijskom i posttranzicijskom vremenu gazi svojim besprizornim hodom prinuđavajući narode i kulture da prihvate samo jedan oblik racionaliteta $\mathrm{u}$ sledećem smislu:

Tehničko -tehnološkom;

Jezičkom;

Menadžersko-konzumentskom smislu, kao simulaciju za kulturu; i

U političkom smislu: jer je na delu svođenje demokratije na proceduru iza koje stoji puka materijalna razmena kao oličenje ekonomske moći, koja se ispostavlja kao distributivna moć selektivne "pravde”.

Svi ti procesi koji vode imperijalnoj moći ne vrhune li u svojim sredstvima: lobiranju, navodno kao legalnom sredstvu, i korupciji, kao nelegalnom sredstvu koja kvari ukupno društveno-državno biće? Kada zarobite jedno društvo na način za- robljavanja države, onda državno-društvene temelje dovodite u pitanje: kulturu, obrazovanje, socijalnu i zdravstvenu zaštitu, vojsku, policiju i pravosuđe, jednom rečju, kada ljude koji rade u javnom sektoru učinite nevidljividim, ne proizvodi li se na taj način industrija korupcije (Darraough, 1999; Svejn et al., 2012) sa svim njenim modalitetima. Diskurs neoliberalne globalizacije počiva na paradigmi da jedino mera stvari ogleda se u mantri da je „država čuvar tržišta” a što upravo znači da državu treba svesti na najmanju moguću meru i svo ljudsko delanje prepustiti tržištu. Taj diskurs se danas nalazi u dekonstruktivnom procesu i nastaje kod mnogih ekonomskih teoretičara kao plod griže svesti kako je rekao Pol Krugman, a isto tako i rodonačelnik čikaške škole, neposredno pred smrt, Milton Fridman, a i Džozef Štiglic u studiji Protivrečnost globalizacije.

Mantru neoliberalne globalizacije, kako bi rekao Derida, njeni teorijski i praktični protagonisti manijačno ponavljaju: živeo neoliberalizam i slobodno tržište sa zapovešću: privatizuj, liberalizuj, deregulatizuj i standardizuj. Jednostavno rečeno: prodajte sve resurse: zemljište, vodu, naftu i vazduh, otvorite granice i uvozite, a potom zemlju tako regionalizujete da potencijalno bude više kvazi društva i standarde tako primenite da vaši građani ni jedan ozbiljan posao ne mogu da otpočnu. Put ka dužnočkom ropstvu na taj način dobro se trasira! Otuda i pitanje: nije li taj duh vremena, u kome je sve predmet kupoprodaje, cirkulacije kapitala - novca - moći put ka razgorevanju korupcije? Naš odgovor je nedvosmislen: razmah korupcije ima svoj izvor u neoliberalizmu, odnosno neoliberalnoj ekonomiji koji pod svoje noge podastire politiku, moral i pravo tj.duh vremena priziva svoju antitezu: intervenciju države, a ako hoćete, državnu intervenciju. Vrtimo se u krugu: počinjemo sa liberalizmom koji prerasta u neoliberalizam, a ovaj u društveni intervencionizam. Očito da je na delu zamka: bez kapitalizma se ne može! Da li je to istina? Mišljenja smo da nije, iz razloga: čovek nije samo biće racionaliteta - interesa, a pogotovo ne biće pohlepe, već je čovek i biće slobode, pa ako hoćete, i utopije.

Naime, ako se informatička tehnologija predočava kao zapovest, onda je engleski jezik zamena za 4.500 živih jezika, posredstvom kojih se odvija komunikacija među ljudima i kulturama na kugli zemaljskoj, i kao takav je, takođe, zapovest. Odatle sledi da je menadžersko-konzumentska kultura, kao potrošačka kultura, zapovedni koncept kulture. Druge kulture kao da ne postoje, ili se pak tretiraju kao kulture zavičajno-običajnog, da ne kažemo mitološkog tipa, i kao takve su vanvremenske, tj. arhaične i anahrone, a održavaju se u svrhu rezervatsko-turističkih atrakcija.

Dakako, ovi uvidi nisu apriorno usmereni ni protiv tehničko-tehnološkog koncepta, ni protiv engleskog jezika, ili potrošačke kulture, kao ni protiv demokratije. Oni samo konstatuju ljudsku-epohalnu potrebu, ako čovek hoće da opstane u ovom svetu, za oživotvorenjem ideje pluraliteta, odnosno za poštovanjem različitosti. Poštovanje različitosti ne može se meriti rezervatskom kulturom turističke atrakcije, nego pravom na punoću života različtih obrazaca i formi života (Gadamer, 1978).

Međutim, ono što nama preostaje jeste da skrenemo pažnju na sledeće. Građanski horizont sveta sa svojim likom: besprizornom i besprimernom praksom globalizacije - ispostavio je ekonomiju kao jedini oblik racionaliteta, odnosno praktičnog (ne)uma koji sva druga praktična ljudska mišljenja/delovanja podastire vlastitoj kalkulativnoj igri sa svrhom osvajanja prirode i ekonomskog porobljavanja čoveka uopše.

Peter Sloterdajk iznosi argumentovanu dijagnozu savremenog kretanja kada ove procese identifikuje sa sve prisutnim zavođenjem čija svrha se ogleda u pristajanju na bestijalnu zabavu koja rezultuje u građaninu koji je „maska duše od novca a koji pokazuje da se uvek radi samo o slobodi ultimativnog 
građanskog interesa: sa što manje muke zaraditi novac na račun drugih, ukratko - o slobodi prirode i društva, o slobodi kretanja robe i novca, slobodi koja mora početi kao zahtev za slobodnom savešću da bi završila kao sloboda od savesti”.

To radikalno prevrednovanje, po našem mišljenju, treba da se ogleda u svetlu neminovnog novog rekonstruisanja odnosa teorijskog, praktičnog i poetičkog uma, koji će svedočiti o potrebnim novim prelazima kojima je stalo do podjednake važnosti i dela i celina, celovitosti i razlike, bez prinudnog nametanja. Taj problem je tim preči unutar momenata praktičnog uma, tj. veza - odnosa - prelaza između moralnog, političkog, ekonomskog i pravnog mišljenja/delovanja uz izbegavanje nametanja i izdvajanja bilo kog ljudskog praktičnog mišljenja/delovanja, jer ako je to na delu, tada stanuje opasnost od jednostrane metafizike bilo: etike, politike, ekonomije ili prava, čime se utire svojevrstan put bilo redukcije moralnog na moralisanje (što je Hegelova primedba Kantu), bilo političkom totalitarizmu, što je oprobano sa staljinizmom i ostalim izmima, bilo globalizmu ili ekonomskom totalitarizmu, što moderan svet živi danas, bilo pravnoj insuficijenciji, što je oprobalo Rimsko carstvo. Bez gradnje otvorenog jedinstva momenata praktičnog uma i njegovih prelaza ka teorijskom i poetičkom, kao i obratno, praksa globalizacije zaista može dovesti i do faktičkog kraja istorije, jer radikalne suprotnosti tako blizu stanuju: tako pri razumnoj i sveprisutnoj kontroli, u njenoj blizini, stanuje nekontrolisani haos, jer njegovo trajanje ne samo da utire put ka kiber-društvu nego i mogućem kiber-ratu, koji bi se po svojim mogućnostima suštinski razlikovao od svih dosad viđenih i doživljenih ratnih tragedija (Virilio, 2000).

\section{REFERENCE}

Adorno, T. (1986). Filozofska terminologija. Sarajevo: Svjetlost.

Berč, K., \& Mihnjenko, V. (2012). Uspon i pad neoliberalizma. Beograd: Zavod za udžbenike.

Darrouhg, M.N. (1999). Privatization and Corruption: Patronage vs. Spoils. International Public Managent Journal, 2(2), 273-298.

Fink, E. (1989). Uvod u filozofiju. Beograd: Nolit.

Gadamer, H.G. (2000b). Um u doba nauke. Beograd: Plato.

Gadamer, H.G. (2000a). Evropsko naslede. Beograd: Plato.

Gadamer, H.G. (1978). Istina i metoda: osnovi filozofske hermeneutike. Veselin Masleša: Sarajevo.

Habermas, J. (1988). Filozofski diskurs moderne. Zagreb: Globus.

Hegel, G.V.F. (1974). Fenomenologija duha. Beograd: BIGZ.

Hobsbaum, E. (2008). Globalizacija, demokratija i terorizam. Beograd: Arhipelag.

Horkheimer, M. (1988). Kritika instrumentalnog uma. Zagreb: Globus.

Lyotard, F. (1991). Raskol. Novi Sad: Izdavačka knjižarnica Zorana Stojanovića.

Virilio, P. (2000). Informatička bomba. Novi Sad: Svetovi.

Welsch, W. (2000). Naša postmoderna moderna. Novi Sad: Izdavačka knjižarnica Zorana Stojanovića. 